\title{
PELAKSANAAN PROGRAM DIRASAH ISLAMIYAH SEBAGAI UPAYA PENINGKATAN KUALITAS SDM MASYARAKAT DI DESA SICINI KABUPATEN GOWA
}

\author{
Chamdar Nur \\ Sekolah Tinggi Ilmu Islam dan Bahasa Arab (STIBA) Makassar \\ chamdarnur@stiba.ac.id
}

Keywords :

Community Service, Islamic

Learning, Quran, Sicini.

\section{ABSTRACT}

One form of community service conducted by STIBA Makassar Community Service Program (KKN) students in Sicini Village, Parigi District, Gowa Regency, was implementation of Islamic education programs (Dirasah Islamiyah). The objective of this program was to enhance Islamic comprehension and competence of people in Sicini. The details of the Islamic learning program consisted of: (1) Presenting Islamic teacing in schools; (2) Basic teaching of Koran at TKA/TPA; (3) Tajwid learning; (4) Dirosa teaching; (5) Training for funeral; and (6) Tabligh Akbar. Outputs of the programs is a positive contribution in improving the comprehension and competence of human resources in muslim community in Sicini Village.

\section{Kata kunci :}

Pengabdian Masyarakat, Dirasah Islamiyah, Al Qur'an, Sicini.

\section{ABSTRAK}

Salah satu bentuk pengabdian masyarakat mahasiswa KKN STIBA Makassar di Desa Sicini, Kecamatan Parigi, Kabupaten Gowa, adalah melaksanakan program pendidikan keislaman (dirasah islamiyah). Tujuan program ini adalah untuk meningkatakan pemahaman dan kompetensi keislaman masyarakat Desa Sicini. Adapun rincian program dirosah islamiyah terdiri dari: (1) Mengajara Pelajaran Agama Islam di Sekolah; (2) Mengajar Al Qur'an Dasar di TKA/TPA; (3) Perbaikan tajwid; (4) Pengajaran dirosa; (5) Pelatihan penyelenggaraan jenazah; dan (6) Tabligh akbar. Luaran program memberikan kontribusi positif dalam meningkatkan pemahaman dan kompetensi sumberdaya manusia masyarakat muslim di Desa Sicini. 


\section{PENDAHULUAN}

\section{Profil Desa Sicini, Kecamatan Parigi, Kabupaten Gowa}

Desa Sicini merupakan salah satu desa dalam wilayah Kecamatan Parigi Kabupaten Gowa. Wilayah Desa Sicini secara umum mempunyai ciri geologis berupa daerah pegunungan dengan hamparan padang ilalang yang dijadikan sebagai tempat rerumputan penggembalaan, dan hutan yang didominasi oleh berbagai jenis kayu hutan alam, serta Desa Sicini Termasuk wilayah Hutan Lindung ,Selain berupa hutan, Desa Sicini juga merupakan Daerah Persawahan, yang umumnya sawah tadah hujan. Kemiringan tanah secara umum di Desa Sicini diperkirakan sekitar $15^{\circ} \mathrm{s} / \mathrm{d} 45^{\circ}$.

Kondisi alam Desa Sicini merupakan daerah pegunungan dengan panorama alam serta hutan yang masih luas. Oleh karena itu, Desa Sicini sangat cocok sebagai tempat yang sangat menarik bagi orang-orang yang memiliki hobbi berburu babi hutan,serta Panorama Alam yang sangat indah apalagi di saat malam hari seluruh wilayah Kota Makassar terlihat dengan jelas. Di sebelah selatan Dusun Siriya, dusun Parangtangaya, Dusun Pattiroang terdapat kawasan Hutan Lindung serta ratusan hektar hamparan rumput ilalang (lahan tidur) yang sangat cocok dijadikan sebagai tempat pemeliharaan ternak.

Secara administratif, wilayah Desa Sicini terlatak di wilayah Kecamatan Parigi Kabupaten Gowa yang merupakan salah satu Desa dari lima Desa yang ada.Wilayah Desa Sicini secara administrasi dibatasi oleh wilayah Kecamatan serta desa tetangga. Adapun secara Demografi Desa Sicini memiliki batas sebagai berikut:

\begin{tabular}{cc}
\hline Arah Batas & Daerah Batas \\
\hline Utara & Desa Jonjo \\
\hline Selatan & Kec. Bungaya \\
\hline Timur & Desa Bilanrengi \\
\hline Barat & Kec. Manuju \\
\hline
\end{tabular}

Luas wilayah Desa Sicini adalah $25,9 \mathrm{~km}^{2}$ yang terdiri dari 510 ha berupa Hutan Lindung, 850 ha berupa sawah yang digunakan untuk lahan pertanian, serta 167 ha berupa ladang. Lahan tidur /pengembalaan 50,2 ha,pemukiman 180 ha. Sebagaimana wilayah tropis, Desa Sicini mengalami musim kemarau dan musim penghujan dalam tiap tahunnya. Rata-rata perbandingan musim penghujan lebih besar daripada musim kemarau, hal itu disebabkan karena wilayah yang masih hijau dengan vegetasi serta relatif dekat dengan wilayah Hutan Lindung Bukit Barisan.

Jarak pusat desa dengan ibu kota kabupaten yang dapat ditempuh melalui perjalanan darat kurang lebih $75 \mathrm{~km}$. Kondisi prasarana jalan poros desa yang masih berupa jalan konstruksi lapen dengan kondisi rusak parah mengakibatkan waktu tempuh menggunakan kendaraan bermotor mencapai kurang lebih 2 jam. Sedangkan jarak pusat desa dengan ibu kota kecamatan yang dapat ditempuh melalui perjalanan darat kurang lebih $13 \mathrm{~km}$. Kondisi ruas jalan poros desa yang dilalui juga berupa jalan

Chamdar Nur. Pelaksanaan Program Dirasah ... 
WAHATUL MUJTAMA': Jurnal Pengabdian Masyarakat

Vol. 1, No. 1 (2020) : Hal. 1-12

Website: https://journal.stiba.ac.id

konstruksi lapen dengan kondisi rusak parah mengakibatkan waktu tempuh menggunakan kendaraan bermotor mencapai kurang lebih 50 menit. Wilayah Desa Sicini yang dijadikan sebagai tempat rerumputan pengembalaan, dan hutan yang didominasi oleh berbagai jenis kayu hutan alam,serta Desa Sicini termasuk wilayah hutan lindung,selain berupa hutan, desa sicini juga merupakan Daerah persawahan ,yang umumnya sawah tadah hujan.Kemiringan tanah secara umum di desa diperkirakan sekitar $15 \mathrm{~s} / \mathrm{d} 45^{\circ} \mathrm{C}$.

Secara historis kata Sicini berasal dari Bahasa Makassar "sicini" yang artinya "berjumpa". Pemberian nama sicini sebagai nama Desa bermula dari pemberian nama sicini pada awal kemerdekaan dalam bentuk Gallarrang yang dipimpin oleh seorang Galla yang bernama Patunai dan dilanjutkan oleh H. Sangi. Kemudian sekitar tahun 1960 terbentuklah desa Parigi yang meliputi wilayah Gallarrang Sicini yang kemudian menjadi nama dusun Sicini.

\section{Peran Pendidikan dalam Meningkatkan Kualitas Sumber Daya Manusia}

Ketahanan suatu masyarakat ditentukan oleh tiga unsur, yaitu 1) sumber daya alam yang memadai, 2) sumber daya manusia yang berkualitas, dan 3) sumber daya kebudayaan dan kesejarahan yang kokoh. ${ }^{1}$ Oleh karena itu, penting untuk senantiasa memperhatikan kapasitas berbagai sumber daya tersebut, khsususnya dalam menghadapi dinamika globalisasi dewasa ini. Era globalisasi tidak akan pernah lepas dari persoalan peningkatan sumber daya manusia, yaitu kualitas manusia yang mencakup keseimbangan aspek material dan aspek spiritual/nilai keagamaan. ${ }^{2}$

Salah satu upaya yang dapat dilakukan untuk meningkatkan berbagai kapasitas sumber daya tersebut adalah melalui proses pendidikan. oleh karena itu, penting membekali masyarakat dengan berbagai pondasi pendidikan dan menjadikannya sebagai bekal utama dalam mempersiapkan masyarakat menghadapi tentangan masa depan. ${ }^{3}$ Pendidikan adalah segala bentuk pengalaman belajar yang berlangsung dalam lingkungan keluarga, sekolah, dan masyarakat untuk mengembangkan kemampuan seoptimal mungkin sejak lahir sampai akhir hayat. ${ }^{4}$ Pembangunan pada berbagai sektor sangat dipengaruhi oleh kualitas sumber daya manusia (SDM) yang ada pada suatu masyarakat. Oleh karena itu, dibutuhkan suatu upaya untuk melakukan sebuah proses peningkatan kualitas pendidikan ke arah yang lebih serius. Pada konteks tersebut pendidikan menjadi yang tempat strategis untuk mengantarkan pada maksud tersebut, dan tentu

\footnotetext{
${ }^{1}$ Henry Alexis Rudolf Tilaar. Membenahi Pendidikan Nasional. (Jakarta: PT Rineka Cipta, 2002): h. 60

${ }^{2}$ Djuwarijah. Peningkatan Kualitas Sumber Daya Manusia Melalui Pendidikan Islam. El Tarbawi, Jurnal Pendidikan Islam, vol.1, No.1, (2008): h.16

${ }^{3}$ Hasan Baharun and Robiatul Awwaliyah, 'Pendidikan Multikultural Dalam Menanggulangi Narasi Islamisme Di Indonesia', Jurnal Pendidikan Agama Islam, Vol.5, No.2 (2017): h.226

${ }^{4}$ Sukarno L. Hasyim. Pendidikan Anak Usia Dini (PAUD) Dalam Perspektif Islam. JURNAL LENTERA: Kajian Keagamaan, Keilmuan dan Teknologi. Vol.1, No.2, (2015): h.217
} 
WAHATUL MUJTAMA': Jurnal Pengabdian Masyarakat

Vol. 1, No. 1 (2020) : Hal. 1-12

Website: https://journal.stiba.ac.id

saja membutuhkan suatu sistem pengelolaan pendidikan yang berkualitas dalam rangka mewujudkannya. ${ }^{5}$ Pembangunan pendidikan nasional didasarkan pada paradigma membangun manusia Indonesia seutuhnya yang berfungsi sebagai subjek yang memiliki kapasitas untuk mengaktualisasikan potensi dan dimensi kemanusiaan secara optimal, diarahkan untuk meningkatkan mutu dan daya saing sumber daya manusia. ${ }^{6}$

Secara umum, pendidikan di Indonesia dimaksudkan dalam rangka meningkatkan kualitas pribadi dan kualitas hidup masyarakat serta bangsa. ${ }^{7}$ Hal ini sebagaimana tertuang dalam Undang-Undang No. 20 tahun 2003 tentang Sistem Pendidikan Nasional yang menyatakan bahwa "Pembangunan nasional dalam bidang pendidikan merupakan upaya mencerdaskan kehidupan bangsa dan meningkatkan kualitas manusia Indonesia dalam mewujudkan masyarakat yang maju, adil dan makmur serta memungkinkan warga negaranya mengembangkan diri, baik berkenaan dengan aspek jasmaniah maupun rohaniah berdasarkan Pancasila dan UUD 1945". Disebutkan juga dalam UU No. 20 tahun 2003, bahwa "Pendidikan nasional bertujuan mengembangkan potensi peserta didik agar manusia yang beriman dan bertaqwa terhadap Tuhan Yang Maha Esa, berakhlak mulia, sehat, berilmu, cakap, kreatif, mandiri, dan menjadi warga negara yang demokratis serta bertanggungjawab dalam rangka mencerdaskan kehidupan bangsa." 8

\section{Peran Pendidikan Islam (Dirasah Islamiyah) dalam Peningkatan Kualitas Sumber Daya Manusia Masyarakat Muslim}

Pendidikan adalah bagian yang tidak terpisahkan dari kehidupan manusia, termasuk di dalamnya Pendidikan Islam. ${ }^{9}$ Dalam literatur Islam, konsep pendidikan dikembangkan dari beberapa term, antara lain tarbiyah, ta'lim dan $t a^{\prime} d i b .{ }^{10}$ Namun Istilah yang sering dirujuk untuk merumuskan konsep pendidikan Islam adalah term "tarbiyah", sehingga penamaan aktivitas pendidikan pada jenjang pendidikan tinggu menggunakan istilah Kulliyat al-Tarbiyah, atau yang di Indonesia disebut dengan Fakultas Tarbiyah. ${ }^{11}$

Pendidikan Islam jelas mempunyai peranan penting dalam peningkatan kualitas SDM. Konferensi Internasional Pertama tentang pendidikan Islam di Mekkah tahun 1977

${ }^{5}$ Ahmad Fauzi. Model Manajemen Pendidikan Islam; Telaah Atas Pemikiran dan Tindakan Sosial. At-Ta'lim, Jurnal Pendidikan. Vol.2, No.2 (2016): h.20

${ }^{6}$ Sukarno L. Hasyim. Pendidikan Anak Usia Dini (PAUD) Dalam Perspektif Islam. JURNAL LENTERA: Kajian Keagamaan, Keilmuan dan Teknologi, Vol.1, No.2 (2015): h.217

7 Ari Hasan Anshori. Strategi Peningkatan Sumber Daya Manusia dalam Pendidikan Islam. JURNAL QATHRUNÂ Vol. 2 No. 2 (2015): h.20

${ }^{8}$ Undang-undang No 20 tahun 2003

${ }^{9}$ Rizka Harfiani dan Mavianti. PKM Peningkatan Kualitas Guru PAUD Dalam Pembelajaran Pendidikan Agama Islam Berbasis Pendidikan Inklusif di Kecamatan Sunggal Kabupaten Deli Serdang. IHSAN: Jurnal Pengabdian Masyarakat, Vol.1, No.1 (2019): h.85

${ }^{10}$ Hasan Langgulung, Asas-asas Pendidikan Islam, (Jakarta: Pustaka Al-Husna, 1992): h.4-5

${ }^{11}$ Ahmad Syah. Term Tarbiyah, Ta'lim, dan Ta'dib dalam Pendidikan Islam: Tinjauan dari Aspek Semantik. Al-Fikra: Jurnal Ilmiah Keislaman, Vol.7, No.1, (2017): h.140

Chamdar Nur. Pelaksanaan Program Dirasah ... 
WAHATUL MUJTAMA': Jurnal Pengabdian Masyarakat

Vol. 1, No. 1 (2020) : Hal. 1-12

Website: https://journal.stiba.ac.id

merumuskan tujuan pendidikan Islam sebagai berikut: ${ }^{12}$ "Pendidikan bertujuan mencapai pertumbuhan kepribadian manusia yang menyeluruh secara seimbang mellaui latihan jiwa, intelek diri manusia, perasaan dan indera. Karena itu pendidikan harus mencakup pertumbuhan manusia dalam segala aspeknya: spritual, intelektual, imajinasi, fisik, ilmiah, bahasa baik secara individual maupun secara kolektif, dan mendorong semua aspek ini kearah perbaikan dan mencapai kesempurnaan. Tujuan terakhir pendidikan muslim terletak pada perwujudan ketundukan hang sempurna kepada Allah baik secara pribadi, komunitas, seluruh ummat manusia.

Tujuan pendidikan Islam dalam konfrensi tersebut sejalan dengan tujuan pendidikan dalam konteks keindonesiaan. Pendidikan Islam diakui sebagai bagian dari subsistem pendidikan Nasional. Hal ini dapat dilihat dari posisi agama (pendidikan agama) dalam UU Sisdiknas 2003. Berbagai pasal menerangkan bahwa pendidikan agama dijadikan sebagai sumber nilai dalam pendidikan nasional. Pendidikan agama memiliki peran cukup penting dalam mengembangkan potensi peserta didik untuk memiliki kekuatan spiritual keagamaan, akhlak mulia dan kepribadian. ${ }^{13}$ Tujuan yang hendak dicapai melalui pendidikan islam tentu memiliki kerangka yang menunjang dalam rangka pencapaian tujuan pendidikan nasional secara umum. ${ }^{14}$ Pendidikan Islam secara teknis akan berupaya untuk meningkatkan kualitas sumber daya manusia yang bermuara pada pembangunan peradaban manusia yang bermartabat. ${ }^{15}$

Visi pendidikan Islam tentunya sejalan dengan visi pendidikan nasional, yaitu mewujudkan manusia Indonesia yang takwa dan produktif sebagai anggota masyarakat Indonesia yang bhinneka. Misi pendidikan Islam sebagai perwujudan visi tersebut adalah mewujudkan nilai-nilai keislaman di dalam pembentukan manusia Indonesia. ${ }^{16}$ Manusia Indonesia yang dicita-citakan adalah manusia yang saleh dan produktif. Hal ini sejalan dengan trend kehidupan abad 21, agama dan intelek akan saling bertemu. ${ }^{17}$

12 Azyumardi Azra. Pendidikan Islam: Tradisi dan Modernisasi di tengah Tantangan Milenium III. (Jakarta: Prenada Media, 2019): h.64

${ }^{13}$ Robiatul Awwaliyah dan Hasan Baharun. Pendidikan Islam Dalam Sistem Pendidikan Nasional (Telaah Epistemologi Terhadap Problematika Pendidikan Islam). Jurnal Ilmiah DIDAKTIKA Vol.19, No. 1, (2018): h.40

${ }^{14}$ Ahmad Furchan, Pengantar Penelitian Dalam Pendidikan, (Yogyakarta: Pustaka Belajar, 2004): h. 14 .

${ }^{15}$ Nurlaila. Model-Model Pengembangan Pendidikan Agama Islam di Sekolah/ Perguruan Tinggi. Ta'dib XVI, (2011): h.270

16 Amiruddin Siahaan. Strategi Pendidikan Islam dalam Meningkatkan Kualitas Sumber Daya Manusia Indonesia. Almufida Vol. I No. 1. (2016): h.2

${ }^{17}$ Henry Alexis Rudolf Tilaar. Paradigma Baru Pendidikan Nasional, (Jakarta: Grasindo, 2004): h. 150

Chamdar Nur. Pelaksanaan Program Dirasah ... 
WAHATUL MUJTAMA': Jurnal Pengabdian Masyarakat

Vol. 1, No. 1 (2020) : Hal. 1-12

Website: https://journal.stiba.ac.id

\section{Upaya Peningkatan Kualitas Sumber Daya Manusia Masyarakat Muslim Di Desa} Sicini

KKN (Kuliah Kerja Nyata) merupakan mata kuliah yang wajib untuk dipenuhi oleh mahasiswa/i Sekolah Tinggi Ilmu Islam dan Bahasa Arab (STIBA) Makassar dalam menyelesaikan beban studinya di perguruan tinggi. Pada tahun akademik 2019/2020 STIBA Makassar menyelenggarakan kerjasama KKN angkatan III dengan pemerintah Kecamatan Parigi Kabupaten Gowa Provinsi Sulawesi Selatan.

Desa Sicini adalah salah satu desa yang menjadi posko penempatan mahasiswa KKN STIBA Makassar angkatan III di wilayah Kecamatan Parigi. Pelaksanaan KKN STIBA Makassar Angkatan III tahun 2020 dimulai pada tanggal 6 Januari 2020 sampai dengan tanggal 24 Februari 2020. Sasaran kegiatan KKN di desa Sicini adalah masyarakat setempat yang terdiri dari berbagai latar usia, mulai dari anak-anak hingga lansia, sehingga program kerja yang direncanakan menargetkan masyarakat dari berbagai kalangan tersebut.

Berdasarkan kondisi tersebut, maka program unggulan yang dilaksanakan di Desa Sicini adalah program Agama Islam yang dikemas melalui program dirasah Islamiyah dan terwejantahkan dalam berbagai kegiatan pendidikan keislaman, untuk meningkatkan kualitas sumber daya masyarakat Islam yang unggul di Desa Sicini. Program ini dinilai tepat diberikan kepada masyarakat desa Sicini yang mayoritas beragama Islam, untuk meningkatkan pemahaman keislaman masyarakat di Desa setempat. Adapun rincian kegiatan dirosah islamiyah yang dirumuskan adalah sebagai berikut.

\begin{tabular}{lcc}
\hline NO & PROGRAM DIROSAH & SASARAN \\
\hline $\mathbf{1}$ & Mengajar Agama Islam di Sekolah & Murid Sekolah Dasar \\
\hline $\mathbf{2}$ & Mengajar Al Qur'an Dasar di & Anak \& Remaja \\
\hline $\mathbf{3}$ & TKA/TPA & Remaja \\
\hline $\mathbf{4}$ & Perbaikan Tajwid & Dewasa \\
\hline $\mathbf{5}$ & Pelatihan Penyelenggaraan Jenazah & Remaja \& Dewasa \\
\hline $\mathbf{6}$ & Tabligh Akbar & Seluruh kalangan \\
\hline
\end{tabular}

\section{PEMBAHASAN}

\section{Gambaran Pelaksanaan Program Dirasah Islamiyah di Desa Sicini}

Kuliah Kerja Nyata (KKN) merupakan salah satu bentuk pelaksanaan pengabdian masyarakat dalam Tridharma Perguruan Tinggi yang sifatnya wajib. Pelaksanaan pengabdian msyarakat dilakukan sesuai dengan budaya akademik, keahlian, dan/atau otonomi keilmuan sivitas akademika dengan mempertimbangkan kondisi sosial budaya masyarakat setempat. Kegiatan Kuliah Kerja Nyata adalah suatu bentuk pendidikan dengan cara memberikan pengalaman empiris kepada mahasiswa untuk hidup di tengah- 
WAHATUL MUJTAMA': Jurnal Pengabdian Masyarakat

Vol. 1, No. 1 (2020) : Hal. 1-12

Website: https://journal.stiba.ac.id

tengah masyarakat luar kampus, dan secara langsung megajarkan kepada mahasiswa cara mengidentifikasi masalah-masalah sosial yang terjadi di masyarakat. Kuliah kerja nyata secara langsung akan menunjukan keterkaitan langsung antara dunia pendidikan dan upaya perwujudan kesejahteraan masyarakat. Tujuan tersebut tersebut dilakukan secara pragmatis, interdisipliner, serta harus tercermin dalam kegiatan-kegiatan mahasiswa pada saat melaksanakan program-program KKN di desa.

Setelah melakukan analisis kebutuhan terhadap warga masyarakat desa Tukamasea, mahasiswa KKN STIBA Makassar mengagendakan berbagai kegiatan dirasah islamiyah yang terdiri dari kegiatan pembelajaran keagamaan untuk meningkatan kualitas pemahaman dan kompetensi membaca keislaman masyarakat di Desa Sicini. Masing-masing uraian pelaksanaan program tersebut dipaparkan sebagai berikut.

\section{1) Mengajar di Sekolah - sekolah}

Kegiatan mengajar yang dilakukan oleh mahasiswa KKN STIBA Makassar Angkatan ke III di sekolah-sekolah yang ada di Desa Sicini. Kegiatan ini merupakan bentuk tindak lanjut dari permintaan kepala sekolah dan guru-guru di desa Sicini. Kegiatan ini mendapatkan respon baik dari kepala sekolah, guru, staf tata usaha, serta berbagai jajaran. Para murid juga sangat antusias dan semangat dalam mengikuti proses belajar yang dibawakan oleh Mahasiswa STIBA Makassar KKN Angkatan ke III. Kegiatan ini berlangsung sejak awal masa KKN hingga selesai masa KKN dan berjalan dengan lancar.

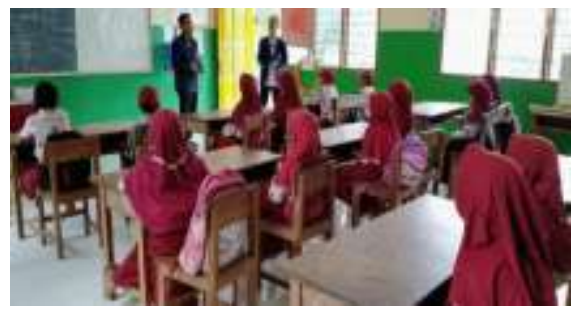

Gambar 1. mengajar Agama Islam di Sekolah

\section{2) Mengajar Al Qur'an Di TK/TPA}

Kegiatan rutin mengajar TK/TPA dimulai dengan silaturahim ke TK/TPA yang ada, terutama di hari-hari awal KKN berlangsung. Mahasiswa KKN STIBA Makassar Desa Sicini melakukan kunjungan ke TK/TPA yang dapat dijangkau. Di hari pertama, kegiatan mengajar TK/TPA lebih banyak didominasi dengan kegiatan perkenalan dan bertukar pengalaman menarik. Proses mengajar TK/TPA berlangsung dengan sangat baik dan mendapatkan banyak kemudahanya karena besarnya antusiasme dari anak-anak untuk belajar. Dalam kesempatan pengabdian ini juga mahasiswa KKN STIBA Makassar membuatkan sistem pengajaran yang lebih terstruktur dan tertata dari segi adminstratif, seperti pengadaan perangkat belajar, buku, dan daftar hadir. 
WAHATUL MUJTAMA': Jurnal Pengabdian Masyarakat

Vol. 1, No. 1 (2020) : Hal. 1-12

Website: https://journal.stiba.ac.id

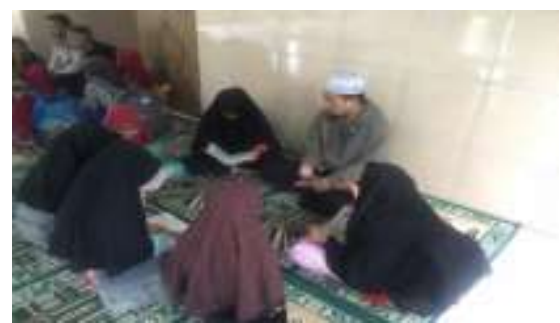

Gambar 2. mengajar di TK/TPA

\section{3) Perbaikan Tajwid}

Proses mengajar tajwid dimulai dari sosialisasi dari masjid ke masjid untuk penawaran bagi para jama'ah remaja di desa Sicini. Hal ini cukup disambut dengan antusias oleh warga yang memiliki semangat dan kemauan dalam mempelajari ilmu tajwid dan cara membaca alquran yang benar. Adapun kendala yang dihadapai dalam pelaksanaan kegiatan perbaikan tajwid adalah adanya beberapa peserta yang belum fasih dalam menyebutkan beberapa huruf alquran. Namun, proses belajar mengajar tajwid ini menjadi wasilah yang tepat dalam memberikan pemahaman membaca Alquran secara baik dan benar.

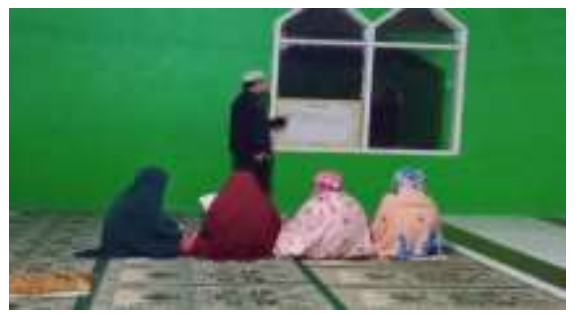

Gambar 3. Mengajar Tajwid

\section{4) Jum'at Ibadah}

Jum'at ibadah bermula dari proses lanjutan silaturahim ke sekolah-sekolah tingkat dasar yang melahirkan sebuah kesepakatan antara pihak Sekolah dengan KKN STIBA Makassar. Kesepakatan tersebut adalah permintaan pihak sekolah kepada Mahasiswa KKN STIBA Makassar untuk menjadi narasumber setiap pekan dalam kegiatan Jum'at Ibadah. Salah satu tantangan yang dihadapi dalam pelaksanaan kegiatan jum'at ibadah ini adalah karena harus mencari bahan materi yang relevan dengan kondisi anak-anak berusia SD. Para peserta jum'at ibadah yang masih berusia SD juga memberikan tantangan tersendiri kepada pemateri jum'at ibadah karena harus menyertakan berbagai permainan yang baru dalam selingan jum'at ibadah. Tujuannya agar membuat peserta tidak bosan dalam mendengarkan ceramah.

Faktor pendukung karena guru begitu senang dan sangat mendukung kehadiran KKN STIBA Makassar, adapun kendala yang kami dapatkan selama jum'at ibadah adalah keributan dan kegaduhan yang sering terjadi saat materi berlangsung, namun dapat diatasi dengan variasi penyampaian dengan selipan ice breaking untuk murid. 


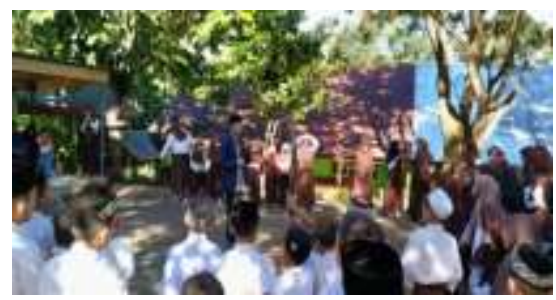

Gambar 4. Jumat Ibadah

\section{5) Mengajar DIROSA}

Kegiatan mengajar dirosa diawali dengan penawaran kepada masyaarakat dari masjid ke masjid setiap selesai salat maghrib. Antusias yang ditunjukkan oleh masyarakat terkhusus para ibu-ibu dan dukungan oleh para tokoh agama menjadi motivasi tersendiri dalam mengajarkan dirosa, terlebih lagi para peserta diberikan bekal saat sosialisasi tentang keutamaan orang-orang yang mempelajari Alqur'an sehingga rasa antusiasme masyarakat semakin bertambah. Hal menarik yang diperoleh dari kegiatan ini adalah adanya ketertarikan irama dan teknis belajar yang berbeda didapatkan oleh masyarakat. Kendala yang terjadi saat proses belajar mengajar dirosa ini adalah buta aksara hurufhuruf Alquran yang masih banyak terjadi di masyarakat, sehingga proses belajar harus dimulai dari pengenalan huruf hijaiyah. Tantangan lainnya adalah, masih kentalnya masyarakat desa dengan motode pembelajaran tradisional (ngaji kampong). Namun seiring waktu masalah ini bisa diatasi dengan rutinitas pertemuan 3 kali sepekan.

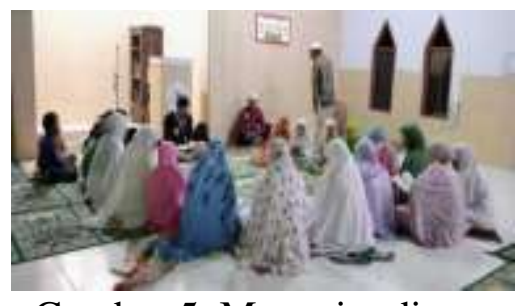

Gambar 5. Mengajar dirosa

\section{6) Pelatihan Penyelenggaraan Jenazah}

Kegiatan Penyelenggaraan jenazah yang dilakukan oleh mahasiswa KKN STIBA Makassar merupakan tindak lanjut dari kegiatan seminar program kerja. Kegiatan pelatihan dibuka langsung secara resmi oleh kepala dusun Parangtangayya, Desa Sicini. Masyarakat cukup antusias dalam menghadiri kegiatan pelatihan tersebut, dan ditandai dengan kehadiran seluruh elemen masyarakat, dimulai dari anak-anak, remaja, hingga dewasa. Salah satu hal menarik dari kegiatan ini adalah, banyaknya ilmu baru yang diperoleh para peserta pelatihan yang dijelaskan oleh mahasiswa KKN STIBA Makassar, sehingga mengundang banyak pertanyaan masyarakat dan penyesuaian keadaan dengan kondisi penyelenggaraan jenazah di desa. Secara umum, kegiatan pelatihan berjalan dengan lancar. 


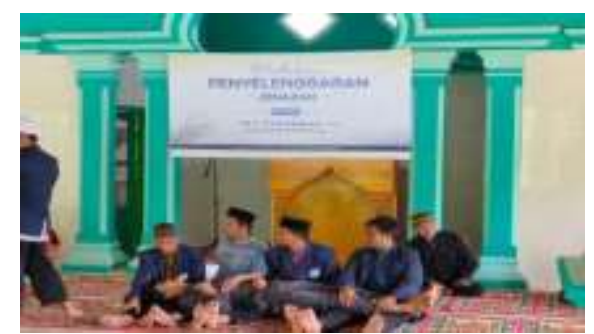

Gambar 6. Pelatihan Penyelenggaraan Jenazah.

\section{7) Tabligh Akbar}

Kegiatan Tabligh Akbar merupakan rangkaian dari kegiatan Festival Anak Saleh yang dimana acara ini diselenggarakan oleh mahasiswa KKN STIBA Makassar kecamatan parigi yang berakhir dengan penyerahan hadiah oleh pemenang lomba Festival Anak Saleh, dan hal yang menarik adalah persaingan juara umum yang begitu ketat antara tiga desa, diantaranya Sicini, Majannang, dan Bilanrengi. Namun pada akhirnya Bilanrengi keluar sebagai juara umum pada kegiatan tersebut. Acara berjalan dengan lancer hingga penutupan selesai.

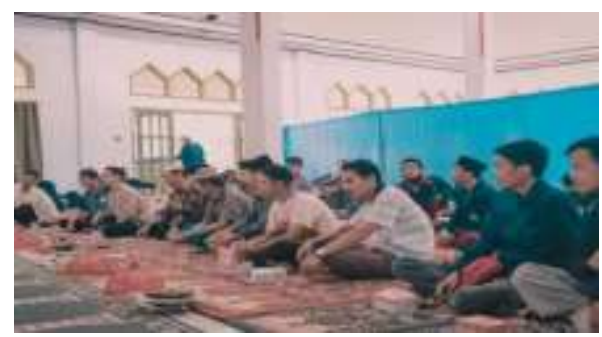

Gambar 8. Peserta Tabligh Akbar

\section{KESIMPULAN}

Pengabdian Kepada Masyarakat (PKM) dalam bentuk program bertujuan untuk menfasilitasi pengembangan SDM masyarakat muslim di Desa Sicini, Kecamatan Parigi, Kabupaten Gowa. Melalui berbagai kegiatan dan program dirosah islamiyah ini warga masyarakat diharapkan memiliki pemahaman dan pengembangan kompetensi keilmuan keislaman yang memadai. Melalui program kegiatan dirosah islamiyah di Desa Sicini, Kecamatan Parigi, Kabupaten Gowa, dapat disimpulkan bahwa kebutuhan mereka terhadap tenaga pengajar dan pembimbing ilmu Islam sangat dibutuhkan di Desa Sicini, khususnya dalam hal pemberantasan buta aksara Al Qur'an. Oleh karena itu, perlu dilakukan upaya yang berkesinambungan dalam menindaklanjuti berbagai program dirasah islamiyah yang dilaksanakan oleh mahasiswa KKN STIBA Makassar angkatan III di Desa Sicini, sehingga manfaat dari program pengabdian masyarakat ini dapat dirasakan secara lebih ajeg dan lebih luas. 


\section{DAFTAR PUSTAKA}

Anshori, A.H. (2015). Strategi Peningkatan Sumber Daya Manusia dalam Pendidikan Islam. JURNAL QATHRUNÂ, Vol.2, No.2, h.19-56

Awwaliyah, R., Baharun, H. (2018) Pendidikan Islam Dalam Sistem Pendidikan Nasional (Telaah Epistemologi Terhadap Problematika Pendidikan Islam). Jurnal Ilmiah DIDAKTIKA, Vol.19, NO.1, h.34-49

Azra, A. (2019). Pendidikan Islam: Tradisi dan Modernisasi di tengah Tantangan Milenium III. Jakarta: Prenada Media.

Baharun, H., Awwaliyah, R. (2017) Pendidikan Multikultural Dalam Menanggulangi Narasi Islamisme Di Indonesia. Jurnal Pendidikan Agama Islam, Vol.5, No.2, h. $224-243$

Djuwarijah. (2008). Peningkatan Kualitas Sumber Daya Manusia Melalui Pendidikan Islam. El Tarbawi, Jurnal Pendidikan Islam, vol.1, No.1, h.(13-26)

Hasyim, S.L. (2015). Pendidikan Anak Usia Dini (PAUD) Dalam Perspektif Islam. JURNAL LENTERA: Kajian Keagamaan, Keilmuan dan Tek nologi, Vol.1, No.2, h. 216-226

Harfiani, R., Mavianti. (2019). PKM Peningkatan Kualitas Guru PAUD Dalam Pembelajaran Pendidikan Agama Islam Berbasis Pendidikan Inklusif di Kecamatan Sunggal Kabupaten Deli Serdang. IHSAN: Jurnal Pengabdian Masyarakat, Vol.1, No.1, h.84-97

Langgulung, H. (1992) Asas-asas Pendidikan Islam. Jakarta: Pustaka Al-Husna

Fauzi, A. (2016). Model Manajemen Pendidikan Islam; Telaah Atas Pemikiran dan Tindakan Sosial. At-Ta'lim, Jurnal Pendidikan. Vol.2, No.2, h.19-37

Furchan, A. (2004) Pengantar Penelitian Dalam Pendidikan. Yogyakarta: Pustaka Belajar

Nurlaila. (2011). Model-Model Pengembangan Pendidikan Agama Islam di Sekolah/ Perguruan Tinggi”' TA’DIB, Vol. XVI, No. 02, h.247-272

Siahaan, A. (2016). Strategi Pendidikan Islam dalam Meningkatkan Kualitas Sumber Daya Manusia Indonesia. Almufida, Vol.I, No.1. h.1-20

Syah, A. (2017). Term Tarbiyah, Ta'lim, dan Ta'dib dalam Pendidikan Islam: Tinjauan dari Aspek Semantik. Al-Fikra: Jurnal Ilmiah Keislaman, Vol. 7, No.1, h.138-150

Tilaar, H.A.R. (2002). Membenahi Pendidikan Nasional, Jakarta: PT Rineka Cipta. 
WAHATUL MUJTAMA': Jurnal Pengabdian Masyarakat

Vol. 1, No. 1 (2020) : Hal. 1-12

Website: https://journal.stiba.ac.id

Tilaar, H.A.R. (2004). Paradigma Baru Pendidikan Nasional. Jakarta: Grasindo.

Undang-undang No 20 tahun 2003 